\title{
Potensi Air Kelapa Muda Dan Air Kelapa Obat Terhadap Pertumbuhan Bakteri Methicillin-Resistant Staphylococcus Aureus (MRSA) dengan Metode Dilusi
}

\author{
Finda Rizky Putri Prabowo ${ }^{1}$, Ikhsan Mujahid ${ }^{2}$, Arif Mulyanto ${ }^{2}$ \\ ${ }^{123}$ Program Studi Teknologi Laboratorium Medik D4, Fakultas Ilmu Kesehatan, Universitas Muhammadiyah \\ Purwokerto, Indonesia.
}

\section{Article Info \\ Article history: \\ Received Mar 01 2021 \\ Revised Aug 30 2021 \\ Accepted Sep $26^{\text {th }} 2021$}

\section{Keyword:}

Wulung coconut, Methicillin-Resistant ,Staphylococcus (MRSA),

Antibiotic resistance

\begin{abstract}
Methicillin-Resistant Staphylococcus aureus is a strain of S. aureus that becomes resistant to the antibiotic activity of the lactam class, including the penicillinase-resistant penicillins (oxacillin, methicillin, nafcillin, cloxacillin, dicloxacillin), cephalosporin, and carbapenem. The coconuts often consumed as medicine are tender coconut and green coconut or often referred to as Wulung coconut which is marked with a pink mesocarp (coir). Wulung coconut is able to treat various types of diseases. The study aimed to determine tender coconut water and green coconut water to inhibit the growth of Methicillin-Resistant Staphylococcus aureus (MRSA) bacteria. This research was conducted in a true experimental with pre-test post-test control group design. It consisted of 6 groups; 2 groups as positive control and negative control and 4 groups treated with green tender coconut water, brown peel tender coconut water, green peel coconut water, and brown peel coconut water. The number of bacteria before and after treatment was counted directly using a hemocytometer and indirectly grown on MHA medium. This study was conducted from July-October 2020. Data were analyzed using a repeated ANOVA test. The results discovered that the effect of coconut water on the number of MRSA bacteria with the direct method, the indirect method, and the comparison of the direct and indirect methods. Brown coconut water is effective in inhibiting the growth of MRSA bacteria by reducing the number of bacteria before treatment $8.2 \mathrm{x}$ $1055.27 \times 105 \mathrm{CFU} / \mathrm{mL}$ to $1.7 \times 1059.01 \times 104 \mathrm{CFU} / \mathrm{mL}$ in the indirect method.
\end{abstract}

\begin{abstract}
ABSTRAK (bahasa Indonesia)
Methicillin-Resistant Staphylococcus aureus merupakan strain S. aureus yang telah resisten terhadap aktivitas antibiotik golongan $\beta$-laktam, termasuk golongan penicillinase-resistant penicillins (oxcacillin, methicillin, nafcillin, cloxacillin, dicloxacillin), cephalosporin dan carbapenem. Kelapa yang sering dimanfaatkan sebagai obat yaitu kelapa muda kulit hijau dan kelapa obat atau sering disebut dengan kelapa wulung yang ditandai dengan bagian mesokarp (sabut) berwarna merah muda. Kelapa wulung memiliki khasiat untuk mengobati berbagai jenis penyakit. Tujuan penelitian ini adalah untuk mengetahui kemampuan air kelapa muda dan air kelapa obat dalam mempengaruhi pertumbuhan bakteri MethicillinResistant Staphylococcus aureus (MRSA). Penelitian ini dilakukan secara true eksperimental dengan rancangan pre test post test control group design. Terdiri dari 6 kelompok dengan 2 kelompok sebagai kontrol positif dan kontrol negatif serta 4 kelompok diberi perlakuan air kelapa muda kulit hijau, air kelapa muda kulit coklat, air kelapa obat kulit hijau, dan air kelapa obat kulit coklat. Jumlah bakteri sebelum dan sesudah perlakuan dihitung secara langsung menggunakan haemocytometer dan tidak langsung
\end{abstract}


ditumbuhkan pada medium MHA. Penelitian ini dilakukan dari bulan Juli-Oktober 2020. Data dianalisis dengan uji repeated ANOVA. Hasil penelitian menunjukkan adanya pengaruh air kelapa terhadap jumlah bakteri MRSA dengan metode langsung, metode tidak langsung, dan perbandingan antara metode langsung dan tidak langsung. Air kelapa obat kulit coklat paling baik dalam menghambat pertumbuhan bakteri MRSA dengan penurunan jumlah bakteri 8,2 x $10^{5} \pm 5,27 \times 10^{5} \mathrm{CFU} / \mathrm{mL}$ sebelum perlakuan menjadi $1,7 \times$ $10^{5} \pm 9,01 \times 10^{4} \mathrm{CFU} / \mathrm{mL}$ setelah perlakuan pada metode tidak langsung.

Kata Kunci : Kelapa obat, Methicillin-Resistant Staphylococcus aureus (MRSA), resisten antibiotik

\section{Pendahuluan}

Infeksi penyakit merupakan salah satu masalah kesehatan yang utama di negara maju maupun berkembang. Infeksi penyakit dapat ditularkan melalui satu orang ke orang lain atau dari hewan ke manusia yang disebabkan oleh berbagai mikroorganisme seperti bakteri, fungi, parasit, maupun virus (Novard et al., 2019). Bakteri S. aureus merupakan salah satu flora normal yang ada pada tubuh manusia yang dapat menyebabkan berbagai penyakit lain seperti jerawat, bisul, infeksi saluran kemih, dan keracunan makanan (Ansari et al., 2016).

Pengobatan infeksi terhadap $S$. aureus paling umum dilakukan dengan pemberian antibiotik. Dampak negatif yang ditimbulkan dari penggunaan antibiotik secara tidak rasional adalah muncul dan berkembangnya resistensi bakteri terhadap antibiotik. Resistensi $S$. aureus terhadap antibiotik telah terus menerus berkembang sejak penggunaan antibiotik penicillin pada tahun 1940. Namun seiring dengan keberhasilan penggunaan penicillin, S. aureus juga menghasilkan enzim penicillinase atau dikenal sebagai $\beta$-laktamase yang dapat menginaktivasi antibiotik penicillin. Selanjutnya pada tahun 1960 digunakan antibiotik methicillin untuk mengatasi Penicillin Resistant Staphylococcus aureus, tetapi 2 tahun kemudian dilaporkan terjadinya kasus Methicillin-Resistant Staphylocccus aureus (MRSA) (WHO, 2018).

MRSA dapat menyebabkan infeksi nosokomial atau infeksi yang terjadi pada fasilitas layanan kesehatan (Ariami et al., 2017). MRSA dapat menyebabkan berbagai macam infeksi, seperti pneumonia, meningitis, bakteremia, saluran pernafasan, tetapi infeksi yang paling sering terjadi pada kulit dan jaringan lunak seperti abses kutaneus furunkel dan selultis (Stenstrom et al., 2009). Terdapat dua mekanisme resistensi bakteri $S$. aureus yaitu dengan menghasilkan enzim $\beta$-laktamase dan gen resisten terhadap methicillin atau gen MecA. Gen MecA yaitu gen penyandi PBP2a (Protein Binding Penicillin 2a) yang mendasari resistensi MRSA (Santiago et al., 2014).

Pengobatan yang umumnya digunakan untuk mengatasi infeksi bakteri resisten antibiotik adalah dengan memanfaatkan senyawa aktif fitokimia yang diperoleh dari bahan alam (Nursidika et al., 2014). Sebagian masyarakat terutama di pedesaan mamanfaatkan air kelapa yang harganya lebih murah dan mudah didapat untuk mengobati diare, cacar, keracunan dan berbagai macam penyakit lainnya. Kelapa yang sering dimanfaatkan sebagai obat yaitu kelapa muda kulit hijau dan kelapa obat yang ditandai dengan bagian mesokarp (sabut) berwarna merah muda (Mansur (2017) dalam Mulyanto et al., 2018).

Berdasarkan hasil pengujian GCMS (Gas Cromatography-Mass Spectometri) menunjukkan bahwa air kelapa obat kulit hijau dan kelapa obat kulit hijau mengandung senyawa aktif yang dominan yaitu geraniol dan senyawa 9-octadecenamide. Geraniol merupakan senyawa alkohol siklik yang termasuk dalam 
golongan monoterpenoid dengan formula $\mathrm{C}_{10} \mathrm{H}_{18} \mathrm{O}$. Geraniol merupakan senyawa antioksidan yang bekerja dengan cara menghambat sintesis DNA (Mujahid dan Mulyanto, 2019), sedangkan senyawa octadecenamide merupakan senyawa yang bersifat antimikroba dan antijamur (Rahbar et al., 2012).

\section{Metode Penelitian}

Penelitian ini termasuk dalam penelitian true eksperimental dengan rancangan pre test post test control group design. Terdiri dari 6 kelompok, 2 kelompok sebagai kontrol positif dan kontrol negatif, serta 4 kelompok diberi perlakuan air kelapa muda kulit hijau, air kelapa muda kulit coklat, air kelapa obat kulit hijau, air kelapa obat kulit coklat. Jumlah bakteri sebelum dan sesudah perlakuan dihitung secara langsung menggunakan haemocytometer dan tidak langsung ditumbuhkan pada medium MHA pengenceran secara duplo. Penelitian dilakukan pada bulan Juli-Oktober 2020 di Laboratorium Mikrobiologi dan Biokimia FKIP UMP. Variabel bebas berupa air kelapa muda dan air kelapa obat, sedangkan variabel terikat berupa bakteri Methicillin-Resistant Staphylococcus aureus (MRSA). Populasi dalam penelitian ini adalah bakteri MRSA, sedangkan sampel dalam penelitian ini adalah bakteri MRSA yang tumbuh. Teknik pengambilan sampel yang digunakan yaitu allocation random sampling. Data dianalisis dengan uji repeated ANOVA.

\section{Hasil Penelitian dan Pembahasan}

Tabel 1. Perhitungan Jumlah Bakteri MRSA Sebelum dan Sesudah Perlakuan dengan Metode Langsung

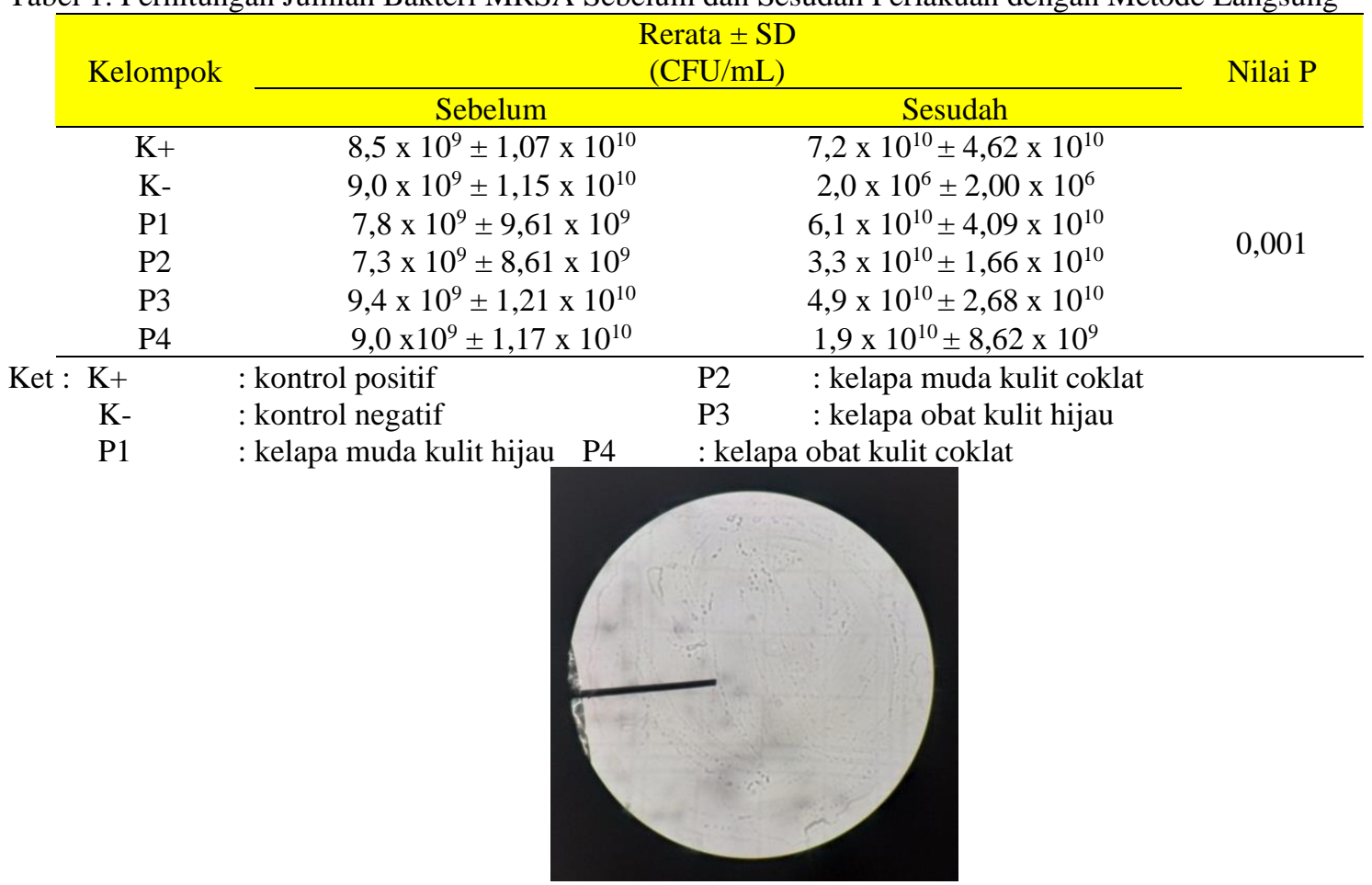

Gambar 1. Penghitungan Secara Langsung pada Haemocytometer 
Tabel 2. Perhitungan Jumlah Bakteri MRSA Sebelum dan Sesudah Perlakuan dengan Metode Tidak Langsung

\begin{tabular}{|c|c|c|c|}
\hline \multirow{2}{*}{ Kelompok } & \multicolumn{2}{|c|}{ Rerata $\pm \mathrm{SD}(\mathrm{CFU} / \mathrm{mL})$} & \multirow{2}{*}{ Nilai P } \\
\hline & Sebelum & Sesudah & \\
\hline $\mathrm{K}+$ & $8,6 \times 10^{5} \pm 6,44 \times 10^{5}$ & $8,1 \times 10^{6} \pm 6,12 \times 10^{6}$ & \multirow{6}{*}{0,010} \\
\hline $\mathrm{K}-$ & $8,4 \times 10^{5} \pm 5,99 \times 10^{5}$ & $0 \pm 0$ & \\
\hline P1 & $7,5 \times 10^{5} \pm 4,99 \times 10^{5}$ & $4,3 \times 10^{6} \pm 3,85 \times 10^{6}$ & \\
\hline $\mathrm{P} 2$ & $8,7 \times 10^{5} \pm 6,44 \times 10^{5}$ & $3,4 \times 10^{6} \pm 2,83 \times 10^{6}$ & \\
\hline P3 & $7,5 \times 10^{5} \pm 5,59 \times 10^{5}$ & $3,1 \times 10^{6} \pm 2,33 \times 10^{6}$ & \\
\hline P4 & $8,2 \times 10^{5} \pm 5,27 \times 10^{5}$ & $1,7 \times 10^{5} \pm 9,01 \times 10^{4}$ & \\
\hline
\end{tabular}
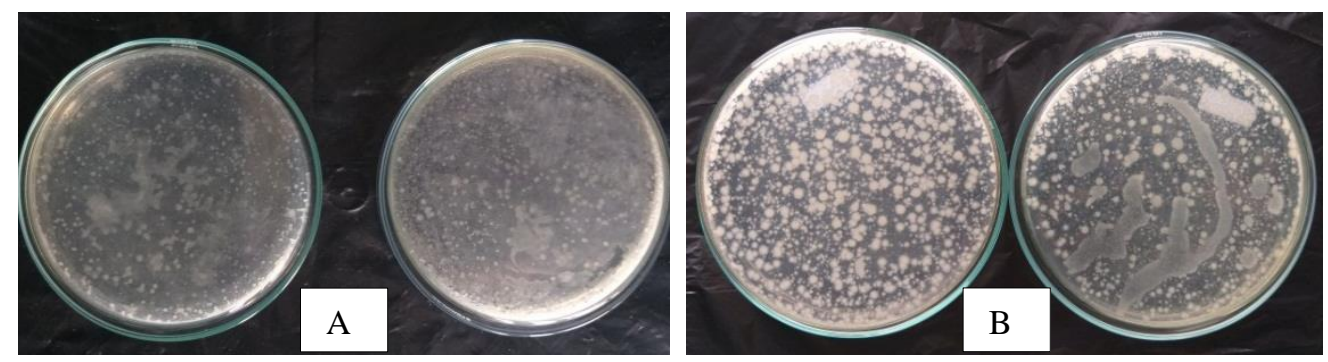

Gambar 1.2. Jumlah Koloni Bakteri MRSA pada Kelompok P4

Ket: (A) Jumlah bakteri sebelum perlakuan (B) Jumlah bakteri sesudah perlakuan

Tabel 3. Perbandingan Perhitungan Jumlah Bakteri MRSA Metode Langsung dan Tidak Langsung

\begin{tabular}{|c|c|c|c|c|c|}
\hline \multirow{3}{*}{ Kelompok } & \multicolumn{4}{|c|}{ Rerata Jumlah Bakteri \pm SD $(\mathrm{CFU} / \mathrm{mL})$} & \multirow{3}{*}{ Nilai P } \\
\hline & \multicolumn{2}{|c|}{ Langsung } & \multicolumn{2}{|c|}{ Tidak Langsung } & \\
\hline & Sebelum & Sesudah & Sebelum & Sesudah & \\
\hline \multirow{2}{*}{$\mathrm{K}+$} & $8,5 \times 10^{9} \pm$ & $7,2 \times 10^{10} \pm 4,62$ & $8,6 \times 10^{5} \pm$ & $8,1 \times 10^{6} \pm 6,12$ & \multirow{12}{*}{1,000} \\
\hline & $1,07 \times 10^{10}$ & $\mathrm{x} 10^{10}$ & $6,44 \times 10^{5}$ & $\times 10^{6}$ & \\
\hline \multirow{2}{*}{ K- } & $9,0 \times 10^{9} \pm$ & $2,0 \times 10^{6} \pm 2,00$ & $8,4 \times 10^{5} \pm$ & $0+0$ & \\
\hline & $1,15 \times 10^{10}$ & $\mathrm{x} 10^{6}$ & $5,99 \times 10^{5}$ & $0 \pm 0$ & \\
\hline \multirow{2}{*}{ P1 } & $7,8 \times 10^{9} \pm$ & $6,1 \times 10^{10} \pm 4,09$ & $7,5 \times 10^{5} \pm$ & $4,3 \times 10^{6} \pm 3,85$ & \\
\hline & $9,61 \times 10^{9}$ & $\mathrm{x} 10^{10}$ & $4,99 \times 10^{5}$ & x $10^{6}$ & \\
\hline \multirow{2}{*}{$\mathrm{P} 2$} & $7,3 \times 10^{9} \pm$ & $3,3 \times 10^{10} \pm 1,66$ & $8,7 \times 10^{5} \pm$ & $3,4 \times 10^{6} \pm 2,83$ & \\
\hline & $8,61 \times 10^{9}$ & $\mathrm{x} 10^{10}$ & $6,44 \times 10^{5}$ & $\mathrm{x} 10^{6}$ & \\
\hline \multirow{2}{*}{ P3 } & $9,4 \times 10^{9} \pm$ & $4,9 \times 10^{10} \pm 2,68$ & $7,5 \times 10^{5} \pm$ & $3,1 \times 10^{6} \pm 2,33$ & \\
\hline & $1,21 \times 10^{10}$ & $\mathrm{x} 10^{10}$ & $5,59 \times 10^{5}$ & $\mathrm{x} 10^{6}$ & \\
\hline \multirow{2}{*}{ P4 } & $9,0 \times 10^{9} \pm$ & $1,9 \times 10^{10} \pm 8,62$ & $8,2 \times 10^{5} \pm$ & $1,7 \times 10^{5} \pm 9,01$ & \\
\hline & $1,17 \times 10^{10}$ & X $10^{9}$ & $5,27 \times 10^{5}$ & $\times 10^{4}$ & \\
\hline
\end{tabular}

Tabel 4. Efektivitas Air Kelapa Muda dan Air Kelapa Obat dalam Menghambat Pertumbuhan Bakteri MRSA

\begin{tabular}{|c|c|c|c|c|}
\hline \multirow{3}{*}{ Kelompok } & \multicolumn{4}{|c|}{ Rerata Jumlah Bakteri \pm SD $(\mathrm{CFU} / \mathrm{mL})$} \\
\hline & \multicolumn{2}{|c|}{ Langsung } & \multicolumn{2}{|c|}{ Tidak Langsung } \\
\hline & Sebelum & Sesudah & Sebelum & Sesudah \\
\hline \multirow{2}{*}{$\mathrm{K}+$} & $8,5 \times 10^{9} \pm$ & $7,2 \times 10^{10} \pm$ & $8,6 \times 10^{5} \pm$ & $8,1 \times 10^{6} \pm$ \\
\hline & $1,07 \times 10^{10}$ & $4,62 \times 10^{10}$ & $6,44 \times 10^{5}$ & $6,12 \times 10^{6}$ \\
\hline \multirow{2}{*}{ K- } & $9,0 \times 10^{9} \pm$ & $2,0 \times 10^{6} \pm$ & $8,4 \times 10^{5} \pm$ & \\
\hline & $1,15 \times 10^{10}$ & $2,00 \times 10^{6}$ & $5,99 \times 10^{5}$ & $0 \pm 0$ \\
\hline \multirow{2}{*}{$\mathrm{P} 1$} & $7,8 \times 10^{9} \pm$ & $6,1 \times 10^{10} \pm$ & $7,5 \times 10^{5} \pm$ & $4,3 \times 10^{6} \pm$ \\
\hline & $9,61 \times 10^{9}$ & $4,09 \times 10^{10}$ & $4,99 \times 10^{5}$ & $3,85 \times 10^{6}$ \\
\hline \multirow{2}{*}{$\mathrm{P} 2$} & $7,3 \times 10^{9} \pm$ & $3,3 \times 10^{10} \pm$ & $8,7 \times 10^{5} \pm$ & $3,4 \times 10^{6} \pm$ \\
\hline & $8,61 \times 10^{9}$ & $1,66 \times 10^{10}$ & $6,44 \times 10^{5}$ & $2,83 \times 10^{6}$ \\
\hline \multirow{2}{*}{ P3 } & $9,4 \times 10^{9} \pm$ & $4,9 \times 10^{10} \pm$ & $7,5 \times 10^{5} \pm$ & $3,1 \times 10^{6} \pm$ \\
\hline & $1,21 \times 10^{10}$ & $2,68 \times 10^{10}$ & $5,59 \times 10^{5}$ & $2,33 \times 10^{6}$ \\
\hline \multirow{2}{*}{ P4 } & $9,0 \times 10^{9} \pm$ & $1,9 \times 10^{10} \pm$ & $8,2 \times 10^{5} \pm$ & $1,7 \times 10^{5} \pm$ \\
\hline & $1,17 \times 10^{10}$ & $8,62 \times 10^{9}$ & $5,27 \times 10^{5}$ & $9,01 \times 10^{4}$ \\
\hline
\end{tabular}


Jurnal Analis Medika Biosains (JAMBS)

Vol.8, No.2, September 2021, pp. 99 - 107

ISSN: 2656-2456 (Online)

ISSN: 2356-4075 (Print)

Sesuai dengan tujuan penelitian ini yaitu untuk mengetahui apakah air kelapa muda dan air kelapa obat dapat menghambat pertumbuhan bakteri Methicillin-Resistant Staphylococcus aureus (MRSA). Penelitian yang telah dilakukan dengan menghitung jumlah bakteri secara langsung menggunakan haemocytometer dan tidak langsung dengan menumbuhkan bakteri hasil peremajaan pada medium MHA secara duplo. Bakteri dari hasil peremajaan dihitung jumlahnya secara langsung dan tidak langsung sebagai data pre test. Bakteri kelompok kontrol positif dimasukkan ke dalam medium $\mathrm{NB}$, kontrol negatif pada DMSO, sedangkan perlakuan 1 pada air kelapa muda kulit hijau, perlakuan 2 pada air kelapa muda kulit coklat, perlakuan 3 pada air kelapa obat kulit hijau, dan perlakuan 4 pada air kelapa obat kulit coklat. Masing-masing diinkubasi selama 1×24 jam, selanjutnya dihitung jumlah bakteri secara langsung dan tidak langsung sebagai data post test.

Berdasarkan hasil penelitian (Tabel 1) penghitungan langsung (haemocytometer) menunjukkan adanya selisih rerata jumlah bakteri MRSA sebelum dan sesudah perlakuan yang ditunjukkan dengan adanya peningkatan jumlah bakteri pada kelompok kontrol K+, K- dan kelompok perlakuan P1, P2, P3, P4. Hasil penghitungan tidak langsung (Tabel 2) menunjukkan adanya peningkatan pada kelompok $\mathrm{K}+, \mathrm{P} 1, \mathrm{P} 2, \mathrm{P}$, sedangkan kelompok K- dan P4 menglami penurunan.

Pada penelitian ini, metode penghitungan jumlah bakteri secara tidak langsung diperoleh hasil yang lebih efektif dibandingkan dengan penghitungan jumlah bakteri secara langsung. Hal ini ditunjukkan dengan jumlah bakteri yang dihitung secara langsung peningkatannya lebih tinggi dibandingkan tidak langsung. Hal tersebut sesuai dengan Alfiyanti dan Putri (2020) yang menyatakan bahwa kelemahan teknik penghitungan secara langsung adalah tidak dapat membedakan sel bakteri yang hidup dan mati. Sedangkan pada teknik penghitungan secara tidak langsung hanya bakteri yang masih hidup saja yang dapat tumbuh pada medium.

Prinsip dari metode penghitungan tidak langsung dilakukan dengan menumbuhkan bakteri pada medium cawan, dimana semua sel bakteri yang masih hidup ditumbuhkan pada medium agar maka sel bakteri tersebut akan berkembang biak dan membentuk koloni yang dapat dihitung menggunakan mata tanpa menggunakan mikroskop. Sedangkan penghitungan secara langsung dilakukan menggunakan alat PetroffHauser Chamber atau Haemocytometer. Pada metode ini bakteri yang tersuspensi akan memenuhi volume ruang pada alat tersebut, beberapa mikroorganisme tertentu cenderung membentuk kelompok atau berantai serta tidak dapat dibedakan antara sel bakteri yang masih hidup dengan sel bakteri yang sudah mati (Wijaya et al., 2015).

Rerata jumlah bakteri pada kontrol positif yang dihitung dengan metode langsung (Tabel 1.) menunjukkan adanya peningkatan jumlah bakteri sebelum perlakuan sebesar $8,5 \times 10^{9} \pm 1,07 \times 10^{10}$ CFU/mL, sedangkan sesudah perlakuan sebesar 7,2 $\times 10^{10} \pm 4,62 \times 10^{10} \mathrm{CFU} / \mathrm{mL}$. Pada metode tidak langsung rerata jumlah bakteri kontrol positif (Tabel 2.) menunjukkan adanya peningkatan jumlah bakteri sebelum perlakuan sebesar 8,6 × $10^{5} \pm 6,44 \times 10^{5} \mathrm{CFU} / \mathrm{mL}$, sedangkan sesudah perlakuan sebesar $8,1 \times 10^{6} \pm$ $6,12 \times 10^{6} \mathrm{CFU} / \mathrm{mL}$. Hal ini sesuai dengan penelitian Wahyuningsih dan Zulaika (2018) yang menyatakan bahwa medium NB baik untuk pertumbuhan bakteri. Penggunaan medium NB sebagai kontrol positif dikarenakan NB merupakan media umum yang digunakan untuk menumbuhkan bakteri secara general. 
Komposisi NB terdiri dari beef extract sebagai sumber karbon dan pepton sebagai sumber nitogen. Formulasi karbon dan nitrogen di dalamnya dapat memenuhi kebutuhan nutrisi bakteri (Wahyuningsih dan Zulaika, 2018).

Rerata jumlah bakteri pada kontrol negatif yang dihitung dengan metode lagsung (Tabel 1.) menunjukkan adanya penurunan jumlah bakteri sebelum perlakuan sebesar 9,0 x $10^{9} \pm 1,15 \times 10^{10} \mathrm{CFU} / \mathrm{mL}$, sedangkan sesudah perlakuan sebesar 2,0 × $10^{6} \pm 2,00 \times 10^{6} \mathrm{CFU} / \mathrm{mL}$. Pada metode tidak langsung rerata jumlah bakteri kontrol negatif (Tabel 2.) menunjukkan adanya penurunan jumlah bakteri sebelum perlakuan sebesar $8,4 \times 10^{5} \pm 5,99 \times 10^{5} \mathrm{CFU} / \mathrm{mL}$, sedangkan sesudah perlakuan sebesar $0 \pm 0 \mathrm{CFU} / \mathrm{mL}$. Hal ini sesuai dengan pendapat Huda et al., (2019) DMSO merupakan pelarut yang dapat melarutkan hampir semua senyawa polar maupun non polar, sehingga jumlah bakteri yang dapat terhitung menurun derastis, bahkan pada akhir perlakuan tidak ada bakteri yang tumbuh. Selain itu, Andayani et al,.(2016) menyatakan bahwa larutan DMSO mempunyai kemampuan untuk menembus membran sel karena dapat menyebabkan pecahnya membran sel. MRSA merupakan bakteri gram positif sehingga saat diberi larutan DMSO 100\% tidak terdapat bakteri yang tumbuh karena membran sel pada bakteri MRSA pecah atau rusak. Hasil tersebut berbanding terbalik dengan penelitian Pratiwi et al., (2011) yang menunjukkan adanya zona hambat ketika DMSO dengan konsentrasi 10\% digunakan sebagai kontrol negatif, sedangkan pada penelitian ini konsentrasi DMSO yang digunakan sebesar 100\%. Hal tersebut kemungkinan dapat mempengaruhi tidak adanya pertumbuhan bakteri.

Berdasarkan hasil statistik penghitungan menggunakan repeated ANOVA rerata jumlah bakteri MRSA sebelum dan sesudah perlakuan yang dihitung dengan metode langsung (Tabel 1.) menunjukan adanya peningkatan jumlah bakteri pada kelompok P1 dari 7,8 x 109 $\pm 9,61 \times 10^{9} \mathrm{CFU} / \mathrm{mL}$ menjadi $6,1 \times 10^{10} \pm 4,09$ x $10^{10} \mathrm{CFU} / \mathrm{mL}$, kelompok P2 meningkat dari 7,3 x $10^{9} \pm 8,61 \times 10^{9} \mathrm{CFU} / \mathrm{mL}$ menjadi $3,3 \times 10^{10} \pm 1,66 \times$ $10^{10} \mathrm{CFU} / \mathrm{mL}$, kelompok P3 meningkat dari $9,4 \times 10^{9} \pm 1,21 \times 10^{10} \mathrm{CFU} / \mathrm{mL}$ menjadi 4,9 $\times 10^{10} \pm 2,68 \times 10^{10}$ $\mathrm{CFU} / \mathrm{mL}$, kelompok P4 meningkat dari $9,0 \times 10^{9} \pm 1,17 \times 10^{10} \mathrm{CFU} / \mathrm{mL}$ menjadi $1,9 \times 10^{10} \pm 8,62 \times 10^{10}$ CFU/mL. Pada metode tidak langsung (Tabel 4.2.) rerata jumlah bakteri pada kelompok P1 meningkat dari 7,5 x $10^{5} \pm 4,99 \times 10^{5} \mathrm{CFU} / \mathrm{mL}$ menjadi 4,3 x $10^{6} \pm 3,85 \times 10^{6} \mathrm{CFU} / \mathrm{mL}$, kelompok P2 meningkat dari 8,7 x $10^{5} \pm 6,44 \times 10^{5} \mathrm{CFU} / \mathrm{mL}$, menjadi $3,4 \times 10^{6} \pm 2,83 \times 10^{6} \mathrm{CFU} / \mathrm{mL}$, kelompok P3 meningkat dari 7,5 $\times 10^{5} \pm$ $5,59 \times 10^{5} \mathrm{CFU} / \mathrm{mL}$, menjadi $3,1 \times 10^{6} \pm 2,33 \times 10^{6} \mathrm{CFU} / \mathrm{mL}$, kelompok P4 menurun dari $8,2 \times 10^{5} \pm 5,27 \times$ $10^{5} \mathrm{CFU} / \mathrm{mL}$ menjadi $1,7 \times 10^{5} \pm 9,01 \times 10^{4} \mathrm{CFU} / \mathrm{mL}$. Adanya peningkatan dan penurunan tersebut dapat terjadi karena adanya perbedaan jenis air kelapa dan teknik penghitungan bakteri yang digunakan. Pada kelompok yang mengalami peningkatan jumlah bakteri terjadi karena dalam air kelapa mengandung glukosa, protein, vitamin dan senyawa lainnya yang dapat mendukung pertumbuhan bakteri, sedangkan kelompok yang mengalami penurunan jumlah bakteri karena adanya senyawa seperti tanin, 9-octadecenamide, dan geraniol yang dapat menghambat pertumbuhan bakteri. Hal ini sesuai dengan hasil penelitian Putra et al., (2019) yang menunjukkan bahwa air kelapa mempunyai efek antimikroba terhadap bakteri.

Mulyanto et al., (2018) menyatakan hasil uji kualitatif melalui penapisan fitokimia yang dilakukan pada air kelapa muda kulit hijau, air kelapa muda kulit coklat, air kelapa obat kulit hijau dan air kelapa obat kulit coklat mengandung tanin. Mekanisme kerja tanin sebagai antibakteri yaitu dengan menghambat enzim reverse transkriptase dan DNA topoisomerase sehingga sel bakteri tidak dapat hidup. Sari dan Sari (2011) 
Jurnal Analis Medika Biosains (JAMBS)

Vol.8, No.2, September 2021, pp. 99 - 107

ISSN: 2656-2456 (Online)

ISSN: 2356-4075 (Print)

menyatakan bahwa tanin mempunyai kemampuan untuk menginaktifkan adhesi sel mikroba, menginaktifkan enzim dan mengganggu transport protein pada sel bakteri. Tanin dapat mengganggu pembentukan polipeptida, dan dinding sel kemudian bakteri menjadi lisis karena adanya tekanan osmotik maupun fisik sehingga sel bakteri mengalami kematian.

Hasil penelitian ini sejalan dengan penelitian Mujahid dan Mulyanto (2019) yang menyatakan bahwa air kelapa dapat menghambat pertumbuhan bakteri. Hal ini terjadi karena air kelapa mengandung senyawa yang berperan sebagai antibakteri. Di dalam air kelapa terdapat senyawa geraniol sebanyak $61.12 \%$ dan octadecenamide sebanyak $7.20 \%$. Geraniol berperan sebagai senyawa antimikroba yang bekerja dengan cara menghambat sintesis DNA pada sel bakteri. Selain geraniol, kelapa obat juga mengandung senyawa 9octadecenamide yang bersifat antimikroba dan antijamur sehingga mampu menghambat pertumbuhan bakteri. 9-octadecenamide termasuk golongan senyawa organik amida dari asam lemak oleat. Senyawa 9octadecenamide mempunyai aktivitas hypolipidemic yang dapat menurunkan kadar lipid dalam sel sehingga dapat menyebabkan lisisnya protoplasma pada bakteri yang dapat mengakibatkan kematian sel bakteri (Anam et al., 2019).

Geraniol merupakan senyawa golongan terpenoid. Senyawa antibakteri jenis terpenoid efektif dalam menghambat pertumbuhan bakteri, jamur, virus, dan protozoa. Mekanisme kerja senyawa ini yaitu bereaksi dengan porin (protein transmembran) yang terdapat pada bagian luar dinding sel bakteri, sehingga terbentuk ikatan polimer kuat yang dapat mengakibatkan rusaknya porin. Porin merupakan molekul protein yang mengatur keluar masuknya senyawa-senyawa tertentu ke dalam sel, seperti glukosa dan asam amino. Kerusakan porin menyebabkan dinding sel bakteri akan mengalami kerusakan karena terjadinya penurunan permeabilitas yang mengakibatkan terganggunya transport ion-ion organik penting yang akan masuk ke dalam sel bakteri, selanjutnya metabolisme di dalam sel terganggu dan bakteri dapat mengalami kematian (Bota et al., 2015).

Hasil uji statistik repeated ANOVA (Tabel 3) rerata jumlah bakteri MRSA sebelum dan sesudah perlakuan dengan metode penghitungan langsung dan tidak langsung menunjukkan tidak adanya perbandingan signifikan antara metode langsung dan metode tidak langsung dengan nilai $\mathrm{p}=1,000$. Adanya perbedaan jumlah bakteri dapat dipengaruhi oleh perbedaan teknik penghitungan yang digunakan.

Berdasarkan Tabel 4. menunjukkan bahwa hasil penghitungan metode langsung terdapat peningkatan rerata jumlah bakteri pada seluruh kelompok perlakuan $\mathrm{K}+, \mathrm{K}-$, P1, P2, P3, dan P4. Pada metode tidak langsung terjadi peningkatan rerata jumlah bakteri pada kelompok perlakuan $\mathrm{K}+, \mathrm{K} 1, \mathrm{P} 1, \mathrm{P} 2$, dan P3 sedangkan P4 terdapat penurunan jumlah bakteri sebesar 8,2 x $10^{5} \pm 5,27 \times 10^{5} \mathrm{CFU} / \mathrm{mL}$ sebelum perlakuan menjadi $1,7 \times 10^{5} \pm 9,01 \times 10^{4} \mathrm{CFU} / \mathrm{mL}$ setelah perlakuan. Sehingga $\mathrm{P} 4$ atau kelapa obat kulit coklat dianggap paling baik dalam menghambat pertumbuhan bakteri MRSA dibandingkan dengan jenis kelapa lainnya.

Adanya peningkatan rerata jumlah bakteri dapat dipengaruhi oleh bakteri yang digunakan pada penelitian ini merupakan bakteri yang resisten terhadap antibiotik Methicillin. Resistensi ini terjadi karena adanya gen MecA yang berperan dalam mengkode PBP2 menjadi PBP2a. Protein ini mempunyai 
kemampuan pertahanan terhadap senyawa antimikroba. Perubahan PBP2a menyebabkan penurunan afinitas Methicillin sehingga bakteri tidak dapat berikatan dengan antibiotik serta pembentukan peptidoglikan tidak terganggu dan bakteri mampu bertahan hidup (Satari, 2010). Selain adanya mekanisme pertahanan dari bakteri MRSA, air kelapa mengandung gula, vitamin, dan juga berbagai jenis mineral yang dapat mendukung pertumbuhan bakteri (Barlina, 2004).

\section{Kesimpulan}

Air kelapa yang efektif dalam menghambat pertumbuhan bakteri MRSA yaitu air kelapa obat coklat.

\section{Daftar Pustaka}

Alfiyanti, E dan Putri, D,H. 2020. Precision of enumeration technique for count of the number of bacterial cells with the spread plate method. Serambi Biologi, 5(1):7-10.

Anam, C., Zaman, M.Z.,Khoirunnisa, U. 2019. Mengungkap Senyawa Pada Nata De Coco Sebagai Pangan Fungsional. Jurnal Ilmu Pangan dan Hasil Pertanian, 3(1):42-53.

Andayani, R., Mubarak, Z., Rinanda, D.R. 2016. Aktivitas Antibakteri Tepung Cacing Tenah (Lumbricus rubellus) Terhadap Enterococcus faecalis Secara In Vitro. Journal Of Syiah Kuala Dentistry Society. $1(2): 201: 210$.

Ansari, S., Gautam, R., Shrestha, S., Ansari, S.R., Subedi, S.N., Chhetri, M.R. 2016. Risk factors assessment for nasal colonization of Staphylococcus aureus and its methicillin resistant strains among pre-clinical medical students of Nepal. BioMedCentral Research Notes, 9:214-221.

Ariami, P., Danuyanti, I., Anggreni, B.R. 2017. Efektifitas Teh Kulit Buah Manggis (Garcinia mangostana L) Sebagai Antimikroba Terhadap Pertumbuhan Bakteri Methicillin Resistant Staphylococcus Aureus (MRSA). Jurnal Teknologi Laboratorium, 3(1).

Barlina, R. 2004. Potensi Buah Kelapa Muda Untuk Kesehatan dan Pengolahannya. Perspektif, 3(2):46-60.

Bota, W., Martosuponoo, M., Rondonuwu, F.S. 2015. Potensi Senyawa Minyak Sereh Wangi (Citronella Oil) dari Tumbuhan Cymbopogon nardus L. Sebagai Agen Antibakteri. Seminar Nasional Sains dan Teknologi, 1-8.

Huda, C., Putri, A.E., Sari, D.W. 2019. Uji Aktivitas Antibakteri Fraksi dari Maserat Zibethinus folium Terhadap Escherichia coli. Jurnal SainHealth, 3(1):7-14.

Mansur, P. S. 2017. Khasiat Kelapa Hijau Bertampuk Merah atau Kelapa Wulung. http://puan.co/2017/04/khasiat-kelapa-hijau-bertampuk-merah-atau-kelapa-wulung/ (diakses tanggal 21 Februari 2020).

Mujahid, I., dan Mulyanto, A. 2019. Deteksi Senyawa Aktif Air Kelapa Obat Metode GCMS dan Minimum Inhibitory Concentration Terhadap Bakteri Patogen Penyebab Diare Dari Pelayanan Kesehatan [Laporan Akhir Penelitian Fundamental]. Universitas Muhammadiyah Purwokerto Press, Purwokerto.

Mulyanto, A., Mujahid, I., Khasanah, T.U. 2018. Kemampuan Air Kelapa Muda Sebagai Antimikroba Terhadap Bakteri Escherichia coli Penyebab Diare. Bio-site, 4(1):18-24.

Novard, M. F.A., Suharti, N., Rasyid, R. 2019. Gambaran Bakteri Penyebab Infeksi Pada Anak Berdasarkan Jenis Spesimen dan Pola Resistensinya di Laboratorium RSUP Dr. M. Djamil Padang Tahun 20142016. Jurnal Kesehatan Andalas, 8(2). 
Nursidika, P., Saptarini, O., Rafiqua, N. 2014. Aktivitas Antimikrob Fraksi Ekstrak Etanol Buah Pinang (Areca catechu L) pada Bakteri Methicillin Resistant Staphylococcus aureus. MKB, 46(2):94-99.

Pratiwi, R.S., Tjiptasurasa, Wahyuningrum, R.2011. Aktivitas Antibakteri Ekstrak Etanol Kayu Nangka (Artocarpus heterophylia Lmk.) terhadap Bacillus subtilis dan Escherichia coli. Pharmacy, 8(3):1-10.

Putra, D.Y., Dewi, S.M., Sidarta, E. 2019. Efek antimikroba air kelapa terhadap pertumbuhan bakteri Salmonella typhi. Tarumanegara Medical Journal, 1(2):291-295.

Rahbar, N., Shafaghat, A., Salimi, F. 2012. Antimicrobial activity and constituents of the hexane extracts from leaf and stem of Origanum vulgare L. ssp. Viride (Boiss) Hayek. Growing wild in Northwest Iran. Journal of Medicinal Plant Research, 6(13): 2681-2685

Santiago, C., Pang, E.L., Kuan, H.L., Hwei, S.L., Ting, K.N. 2014. Reversal of Ampicillin Resistance in MRSA via Inhibition of Penicillin-Binding Protein 2a by Acalypha wilkesiana. BioMed Research International, 1-7.

Sari, F.P., Sari, S.M. 2011.Ekstraksi Zat Aktif Antimikroba dari Tanaman Yodium (Jatropha multifida Linn) Sebagai Bahan Bahan Baku Alternatif Antibiotik Alami. Technical report. Fakultas Teknik, Universitas Diponegoro.

Satari, M.H. 2010. Multidrugs Resistance (MDR) Bakteri Terhadap Antibiotik. Microbiology. Fakultas Kedokteran Gigi, Universitas Padjajaran.

Stenstrom, R., Grafstein, E., Romney, M., Fahimi, J., Harris, D., Hunte, G., Innes, G., Christenson, J. 2009. Prevalence of and risk factors for methicillin-resistant Staphylococcus aureus skin and soft tissue infection in a Canadian emergency department. CJEM, 11(5):430-438.

Wahyuningsih, N dan Zulaika, E. 2018. Perbandingan Pertumbuhan Bakteri Selulolitik Pada Media Nutrient Broth dan Carboxy Methyl Cellulose. Jurnal sains dan Seni ITS, 7(2):36-38.

Wijaya, R.C., Utari, E.L., Yudianingsih. 2015. Perancangan Alat Penghitung Bakteri. Jurnal Teknologi Informasi, 10(29).

World Health Organization. 2018. Antimicrobial resistance. https://www.who.int/news-room/factsheets/detail/antimicrobial-resistance. (diakses tanggal 15 Januari 2020) 